JOURNAL OF PUBLIC HEALTH INOVATION,

VOL. 01 NO.02. JUNI 2021

DOI: $\underline{10.34305 / \text { jphi.v1i2.280 }}$
Ciptaan disebarluaskan di bawah

Lisensi Creative Commons Atribusi-

NonKomersial-BerbagiSerupa 4.0

\title{
HUBUNGAN ANTARA USIA IBU HAMIL DENGAN KEJADIAN PREEKLAMPSIA DI RUMAH SAKIT UMUM DAERAH 45 KUNINGAN
}

\author{
Tia Srimulyawati, Abdal Rohim, Anggit Kartikasari, Ekayani \\ STIKes Kuningan \\ tiasrim89@gmail.com
}

\begin{abstract}
Abstrak
Preeklampsia adalah hipertensi yang timbul setelah 20 minggu kehamilan disertai dengan proteinuria dan dapat terjadi ante, intra, dan postpartum. Berdasarkan dari Sub bagian Rekam Medik RSUD 45 Kuningan data Januari sampai Desember Tahun 2018 ibu yang mengalami preeklampsia sebanyak 139 orang. Penelitian ini bertujuan untuk mengetahui Hubungan antara usia ibu hamil dengan kejadian preeklampsia di Rumah Sakit Umum Daerah 45 Kuningan tahun 2019. Jenis penelitian analitik dengan desain cross sectional. Populasi ibu hamil di RSUD 45 Kuningan tahun 2019 sebanyak 187. Menggunakan teknik total sampling. Instrumen menggunakan Lembar Ceklis. Dengan analisa data menggunakan Chi-square. Sebagian besar usia ibu hamil kategori usia baik yaitu sebanyak 107 responden $(57,2 \%)$ dan ibu hamil dengan preeklampsia berat yaitu sebanyak 134 responden $(71,7 \%)$. Tidak terdapat hubungan antara usia ibu hamil dengan kejadian preeklampsia di Rumah Sakit Umum Daerah 45 Kuningan tahun 2019 p-value $=0,381$. Tidak terdapat hubungan antara usia ibu hamil dengan kejadian preeklampsia disarankan dapat merencanakan kehamilan di usia produktif yaitu usia 20-35 tahun karena rentang usia tersebut kerja organ reproduksi telah maksimal dan tidak termasuk risiko tinggi. Diharapkan Rumah Sakit Umum Daerah 45 Kuningan dapat lebih meningkatkan pelayanan, memantau secara berkala terhadap pasien preeklampsia sehingga dapat mengurangi angka kematian ibu akibat preeklampsia.
\end{abstract}

Kata Kunci : Usia ibu hamil, Kejadian preeklampsia

\section{Pendahuluan}

Indikator angka Kematian Ibu (AKI) atau Maternal Mortality Rate (MMR) manggambarkan besarnya risiko kematian ibu pada fase kehamilan, persalinan dan masa nifas di antara 100.000 kelahiran 
JOURNAL OF PUBLIC HEALTH INOVATION,

VOL. 01 NO.02. JUNI 2021

DOI: $\underline{10.34305 / \text { jphi.v1i2.280 }}$

hidup dalam satu wilayah pada kurun waktu tertentu. AKI berdasarkan laporan rutin Profil kesehatan di Jawa Barat tahun 2016, tercatat jumlah kematian Ibu Bersalin sebanyak 202 orang $(21,32 / 100.000 \mathrm{KH})$ dan pada Ibu Nifas sebanyak 380 orang $(40,32 / 100.000 \mathrm{KH}), \quad$ sedangkan di Kabupaten Kuningan tercatat (131/100.000 $\mathrm{KH})$. Jadi kematian ibu masih menjadi masalah dalam dunia kesehatan (Kementerian Kesehatan, 2016).

AKI adalah salah satu indikator untuk melihat keberhasilan upaya kesehatan ibu dan rasio kematian ibu selama masa kehamilan, persalinan dan nifas yang disebabkan oleh kehamilan, persalinan dan nifas atau pengelolaannya tetapi bukan karena sebab-sebab lain seperti kecelakaan atau terjatuh disetiap 100.000 kelahiran hidup. Disamping itu untuk menilai program kesehatan ibu yaitu dengan menilai derajat kesehatan masyarakat, karena sensitifitasnya terhadap perbaikan pelayanan kesehatan sehingga secara umum terjadi penurunan kematian ibu selama periode 1999- 2015 dari 390 per 100.000 kelahiran hidup. Walaupun terjadi penurunan namun tidak berhasil mencapai target MDGs yang harus dicapai yaitu sebesar 102 per 100.000 per kelahiran hidup pada tahun 2015. Hasil supas tahun 2015
Ciptaan disebarluaskan di bawah

Lisensi Creative Commons Atribusi-

NonKomersial-BerbagiSerupa 4.0 Internasional

memperlihatkan angka kematian ibu tiga kali lipat dibandingkan target MDGs. Target penurunan AKI ditentukan melalui tiga model Average Reduction Rate (ARR) atau angka penurunan rata-rata kematian ibu. Dari ketiga model, kementrian kesehatan menggunakan model kedua dengan rata-rata penurunan 5,5\% pertahun sebagai target kinerja. Berdasarkan model tersebut diperkirakan pada tahun 2030 AKI di Indonesia turun menjadi 131 per 100.000 kelahiran hidup . Upaya laju penurunan AKI dapat dilakukan dengan menjamin agar setiap ibu mampu mengakses pelayanan kesehatan ibu yang berkualitas, seperti pelayanan kesehatan ibu hamil, pertolongan persalinan oleh tenaga kesehatan terlatih di fasilitas pelayanan kesehatan, perawatan pasca persalinan bagi ibu dan bayi, perawatan khusus dan rujukan jika terjadi komplikasi, dan pelayanan keluarga berencana termasuk KB pasca persalinan (Dinas Kesehatan, 2018a).

AKI berdasarkan hasil survey yang dilaksanakan Badan Pusat Statistik (BPS) Provinsi Jawa Barat tahun 2003 memperhitungkan sebesar 321,15 per 100.000 kelahiran hidup dengan pembagian perkelompok wilayah. Dapat dilihat diwilayah Pantura dan Cirebon merupakan AKI terbesar, sedangkan yang terkecil 
JOURNAL OF PUBLIC HEALTH INOVATION,

VOL. 01 NO.02. JUNI 2021

DOI: $10.34305 /$ jphi.v1i2.280

berada di Bandung Raya dan Bodebek. Jumlah Kematian Ibu di Kabupaten Kuningan menunjukan data yang fluktuasi, tahun 2009 ke tahun 2011 ada penurunan kasus tetapi meningkat kembali di tahun 2012 dan 2013. Fakta di lapangan menunjukan bahwa pelaporan data institusi kesehatan masih belum dapat mengakomodasi kebutuhan informasi yang akurat, sehingga tidak dapat dijadikan sebagai tolak ukur keberhasilan. Berdasar hasil pelacakan dan Audit Maternal Perinatal ternyata kematian maternal pada tahun 2013 dipicu karena komplikasi yaitu perdarahan (6 kasus), hipertensi dalam kehamilan (4 kasus) dan penyebab lain (9 kasus) (Dinas Kesehatan, 2018b). Angka kematian ibu (AKI) merupakan salah satu indikator untuk melihat derajat kesehatan perempuan dan salah satu target yang telah ditentukan dalam tujuan pembangunan milenium yaitu tujuan ke 5 yaitu meningkatkan kesehatan ibu dimana target yang akan dicapai sampai tahun 2015 adalah menurunkan $3 / 4$ risiko jumlah kematian ibu. Dari hasil survei yang dilakukan AKI menunjukan penurunan dari waktu ke waktu, namun cara untuk melaksanakan target tujuan pembangunan millenium masih membutuhkan komitmen dan usaha keras yang terus menerus
Ciptaan disebarluaskan di bawah Lisensi Creative Commons AtribusiNonKomersial-BerbagiSerupa 4.0 Internasional.

(Nurasiah et al., 2014). Umumnya ukuran yang digunakan untuk menilai baik buruknya keadaan pelayanan kebidanan (maternity care) dalam suatu negara atau daerah ialah kematian maternal (maternal mortality). Menurut definisi WHO "kematian maternal yaitu kematian seorang wanita pada saat hamil atau dalam 42 hari sesudah berakhirmya kehamilan oleh faktor penyebab apapun itu, terlepas dari tuanya kehamilan dan perbuatan yang dilakukan untuk menghentikan kehamilan." Sebabsebab ini dapat dibagi dalam 2 golongan, yakni yang langsung diakibatkan oleh komplikasi-komplikasi kehamilan, persalinan dan nifas, dan sebab-sebab lain seperti kanker, penyakit jantung, dan sebagainya ( associated causes), angka kematian maternal ( maternal mortality rate) merupakan jumlah kematian maternal dengan perhitungan terhadap 1.000 atau 10.000 kelahiran hidup. Secara global $80 \%$ kematian ibu tergolong pada kematian ibu langsung. Contoh penyebab langsung, yaitu hipertensi dalam kehamilan (12\%), perdarahan pasca persalinan (25\%), sepsis (15\%), komplikasi aborsi tidak aman (13 $\%)$, partus macet $(8 \%)$, dan sebab-sebab lain $(8 \%)$. Eklampsia kebanyakan terjadi pada $0,5 \%$ kelahiran hidup dan $4,5 \%$ hipertensi dalam kehamilan. Pasca konvulsi 
JOURNAL OF PUBLIC HEALTH INOVATION,

VOL. 01 NO.02. JUNI 2021

DOI: $10.34305 /$ jphi.v1i2.280

pada eklampsia mampu membawa dampak kerusakan ginjal, edema paru, hati, ablasio retina, dan perdarahan serebral (Prawihardjo, 2016). Reproduksi sehat yaitu dari usia 20-30 tahun agar usia aman untuk kehamilan dan persalinan. Kematian maternal pada wanita hamil dan melahirkan pada usia dibawah 20 tahun ternyata 2 sampai 5 kali lebih tinggi daripada kematian maternal yang terjadi pada usia 20 sampai 29 tahun. Kematian maternal meningkat kembali sesudah usia 30 sampai 35 tahun (Prawihardjo, 2016) dalam (Monica, 2017). Preeklampsia adalah hipertensi yang muncul setelah 20 minggu kehamilan disertai dengan proteinuria dan dapat terjadi ante, intra, dan postpartum. Pada umumnya ibu hamil dengan usia kehamilan di atas 20 minggu diikuti dengan kenaikan tekanan darah di atas normal sering ditautkan dengan preeklampsia, dengan adanya data atau informasi awal terkait tekanan darah sebelum hamil akan sangat membantu petugas kesehatan untuk membedakan hipertensi kronis (yang sudah ada sebelumnya) dengan preeklampsia (Prawihardjo, 2016).

Hipertensi ialah tanda terpenting guna menetapkan diagnosis hipertensi dalam kehamilan. Tekanan diastolik menunjukkan besaran curah jantung. Pada preeklampsia
Ciptaan disebarluaskan di bawah

Lisensi Creative Commons Atribusi-

NonKomersial-BerbagiSerupa 4.0

Internasional.

peningkatan reaktivitas vaskular dimulai usia kehamilan 20 minggu, tetapi hipertensi dideteksi umumnya pada trimester II. Tekanan darah yang tinggi pada preeklampsia bersifat labil dengan diikuti irama sirkadian normal. Tekanan darah menjadi normal beberapa hari pasca persalinan, kecuali beberapa kasus preeklampsia berat ditandai dengan kembalinya tekanan darah normal pada 2-4 minggu pasca persalinan. Munculnya hipertensi adalah akibat vasopasme menyeluruh dengan ukuran tekanan darah $\geq$ 140/90 mmHg selang 6 jam. Tekanan diastolik ditentukan pada hilangnya suara Korotkoff s phase V. Batas dari hipertensi tekanan diastolik adalah $90 \mathrm{mmHg}$ yang disertai proteinuria, mempunyai kesesuaian dengan kematian perinatal tinggi. Mengingat proteinuria berkaitan dengan nilai absolut tekanan darah diastolik, maka kenaikan (perbedaan) tekanan darah tinggi tidak digunakan sebagai kriteria diagnosis hipertensi, hanya sebagai tanda waspada (Prawihardjo, 2016).

Proteinuria ialah syarat dari diagnosis preeklampsia, tetapi proteinuria umumnya muncul pada akhir kehamilan, sehingga sering dijumpai preeklampsia tidak disertai proteinuria, disebabkan janin sudah lahir lebih dulu. Bila proteinuria timbul sebelum 
JOURNAL OF PUBLIC HEALTH INOVATION,

VOL. 01 NO.02. JUNI 2021

DOI: $10.34305 /$ jphi.v1i2.280

hipertensi, lazimnya ialah gejala penyakit ginjal, jika tidak disertai hipertensi maka dapat dipertimbangkan sebagai penyulit kehamilan, jika tidak ditandai dengan peningkatan tekanan darah diastolik $\geq 90$ $\mathrm{mmHg}$, sering didapati pada infeksi saluran kencing atau anemia tidak biasa ditemukan proteinuria pada tekanan diastolik $<90$ $\mathrm{mmHg}$. Proteinuria ditandai dengan adanya $300 \mathrm{mg}$ protein dalam urine selama 24 jam atau sama dengan $\geq 1+$ dipstick (Prawihardjo, 2016). Edema sering dijumpai pada kehamilan normal dengan memiliki banyak interpretasi, misalnya 40 $\%$ edema dijumpai pada kehamilan normal, $60 \%$ edema didapati pada kehamilan dengan hipertensi dan proteinuria. Edema terjadi karena hipoalbuminemia atau kerusakan sel endotel kapilar. Edema yang patologik ialah edema yang nondependen pada muka dan tangan, atau edema generalisata, dan biasanya diikuti dengan peningkatan berat badan yang cepat (Prawihardjo, 2016).

Banyak penelitin sudah dilakukan untuk mencari faktor risiko, etiologi, dan pencegahan preeklampsia atau eklampsia. Tetapi sampai saat ini belum diketahui pasti untuk mencegah terjadiya preeklampsia atau eklampsia. Oleh sebab itu, pencegahan preeklmpsia atau eklampsia sangat penting
Ciptaan disebarluaskan di bawah

Lisensi Creative Commons Atribusi-

NonKomersial-BerbagiSerupa 4.0

Internasional.

dilakukan terutama dengan mengetahui lebih awal dari faktor risiko preeklampsia atau eklampsia. (Prawihardjo, 2016) dalam (Harli, 2018). Penelitian yang dilakukan oleh (Rozikhan, 2007) menunjukan ibu yang berusia >35 tahun menggambarkan faktor risiko pada kejadian preeklampsia dengan nilai OR 2.75. Pada usia $<20$ tahun dan $>35$ tahun risiko kejadian preeklampsia ibu melahirkan adalah 3,67 kali lebih besar, namun berdasarkan hasil penelitian yang dilakukan oleh (Rozikhan, 2007) di RS Dr. H Soewondo Kendal dan (Dewi, 2017) di RS Syaiful Anwar Malang merumuskan dengan tidak adanya hubungan yang disignifikan antara usia dengan kejadin preeklampsia. Berdasar dari Sub bagian Rekam Medik Rumah Sakit Umum Daerah (RSUD) 45 Kuningan bahwa mulai Januari sampai Desember Tahun 2018 terdapat 139 orang ibu yang mengalami preeklampsia.

Tujuan dari penelitian ini ialah untuk mengetahui "Hubungan antara usia ibu hamil dengan kejadian preeklampsia di Rumah Sakit Umum Daerah 45 Kuningan tahun 2019".

\section{Metode}

Penelitian ini menggunakan metode penelitian analitik dengan pendekatan cross sectional. Pengambilan sampel 
JOURNAL OF PUBLIC HEALTH INOVATION,

VOL. 01 NO.02. JUNI 2021

DOI: $\underline{10.34305 / \text { jphi.v1i2.280 }}$

menggunakan total sampling berjumlah 187 responden. Subjek penelitian ini adalah semua ibu hamil yang bersedia menandatangani lembar persetujuan setelah
Ciptaan disebarluaskan di bawah

Lisensi Creative Commons Atribusi-

NonKomersial-BerbagiSerupa 4.0 Internasional.

diberikan

penjelasan.

Penelitian

dilaksanakan di RSUD 45 kuningan pada bulan Juli tahun 2019.

\section{Hasil}

Tabel 1. Distribusi frekuensi kejadian preeklampsia di RSUD 45 Kuningan Kuningan

Tahun 2019

\begin{tabular}{cccc}
\hline No & Preeklampsia & (f) & $(\boldsymbol{\%})$ \\
\hline 1 & Ringan & 53 & 28.3 \\
2 & Berat & 134 & 71.7 \\
\cline { 2 - 4 } & Total & $\mathbf{1 8 7}$ & $\mathbf{1 0 0}$ \\
\hline
\end{tabular}

Tabel 2. Distribusi frekuensi antara usia ibu hamil dengan kejadian preeklampsia di RSUD 45 Tahun 2019

\begin{tabular}{cccccc}
\hline \multirow{2}{*}{ Usia } & \multicolumn{4}{c}{ Preeklampsia } & p-value \\
\cline { 2 - 5 } & \multicolumn{3}{c}{ Ringan } & Berat & \\
\cline { 2 - 5 } & $\mathrm{N}$ & $\%$ & $\mathrm{~N}$ & $\%$ & \\
\hline $\begin{array}{c}<20 \text { tahun dan }>35 \\
\text { tahun }\end{array}$ & 20 & 25 & 60 & 75.0 & 0,381 \\
20 tahun -35 tahun & 33 & 30.8 & 74 & 69.2 & \\
\hline Total & $\mathbf{5 3}$ & $\mathbf{2 8 . 3}$ & $\mathbf{1 3 4}$ & $\mathbf{7 1 . 7}$ \\
\hline
\end{tabular}

\section{Pembahasan}

Gambaran Usia Ibu Hamil dengan Kejadian Preeklampsia di RSUD 45 Kuningan

Berdasarkan hasil penelitian dapat diketahui bahwa dari 187 responden yang diteliti sebagian besar memiliki usia baik untuk hamil yaitu sebanyak 107 responden (57,2 \%). Hasil penelitian (Hanum, 2013) ditemukan dari jumlah 9 orang responden yang berusia $<20$ tahun dan $>35$ tahun 
JOURNAL OF PUBLIC HEALTH INOVATION,

VOL. 01 NO.02. JUNI 2021

DOI: $\underline{10.34305 / \text { jphi.v1i2.280 }}$

didapati responden menderita preeklampsia ringan sebanyak 1 orang $(11,1 \%)$, preeklampsia berat 8 orang $(88,9 \%)$, dan dari 30 responden berusia 20 -35 tahun yang menderita preeklampsia ringan sebanyak 5 orang $(16,7 \%)$, preeklampsia berat 25 orang $(83,3 \%)$. Dari hasil uji Chi square dihasilkan bahwa tidak ada hubungan antara usia ibu yang hamil dengan kejadian preeklampsia. Ditunjukan dengan nilai X2 hitung $=0,1762$ lebih kecil dari X2 tabel maka Ho diterima dan Ha ditolak. Dilihat secara signifikan dimungkinkan sebagian besar usia ibu adalah usia reproduksi. Berdasar hasil peelitian yang telah dilakukan, maka bisa disimpulkan bahwatidak ada hubungan antara usia, paritas, pendidikan dan pekerjaan ibu hamil dengan kejadian preeklampsia.

Gambaran Kejadian Preeklampsia di RSUD 45 Kuningan

\section{Berdasarkan tabel 2 dapat} diketahahui bahwa dari 187 responden yang diteliti sebagian besar menderita preeklampsia berat sebesar 134 responden (71,7\%). Menurut penelitian (Sunarto, 2016) menunjukan bahwa pengaruh usia ibu dengan kejadian preeklampsia dari 59 sampel, usia ibu remaja <20 tahun yang mengalami preeklampsia ringan sebesar $(6,1 \%)$, preeklampsia berat sebesar $(3,8 \%)$.
Ciptaan disebarluaskan di bawah

Lisensi Creative Commons Atribusi-

NonKomersial-BerbagiSerupa 4.0 Internasional.

Usia ibu dewasa awal 20-35 tahun yang mengalami preeklampsia ringan sebesar $(78,8 \%)$, preeklampsia berat sebesar $(69,2$ $\%)$. Sedangkan usia ibu dewasa akhir $>35$ tahun yang mengalami preeklampsia ringan sebesar $(15,2 \%)$, preeklampsia berat sebesar $(26,9 \%)$. Hasil uji statistik diperoleh nilai $\mathrm{p}=0,697$ atau $\mathrm{p}>0,05$, maka dapat disimpulkan bahwa tidak terdapat hubungan antara usia ibu dengan kejadian preeklampsia.

Hubungan antara Usia Ibu Hamil dengan Kejadian Preeklampsia di Rumah Sakit Umum Daerah 45 Kuningan Tahun 2019

Berdasarkan uraian tabel 3 dapat disimpulkan bahwa dari 187 responden, lebih banyak responden dengan usia baik untuk hamil sebanyak 107 responden (57,2 $\%)$, sebagian besar mengalami pre eklamsia kategori berat yaitu sebesar 74 responden $(69,2 \%)$. Berdasarkan hasil penelitian bahwa kejadian preeklampsia di Rumah Sakit Umum Daerah 45 Kuningan Tahun 2019 dilihat dari hasil uji statistik menggunakanan Chi-Square dibantu oleh aplikasi SPSS didapatkan $\mathrm{p}$-value $=0,381$ (> 0,05) artinya tidak terdapat hubungan signifikan antara usia ibu dengan preeklampsia dan besar risiko (OR) dari yang memiliki usia kurang baik untuk hamil 
JOURNAL OF PUBLIC HEALTH INOVATION,

VOL. 01 NO.02. JUNI 2021

DOI: $\underline{10.34305 / \text { jphi.v1i2.280 }}$

mengalami preeklampsia sebesar 0,747

dibanding yang usia baik untuk hamil.

\section{Kesimpulan}

Hasil penelitian dari 187 responden sebagian besar berusia 20-35 tahun, sebagian besar mengalami preeklampsia berat di RSUD 45 Kuningan tahun 2019.

\section{Referensi}

Dewi, A. I. (2017). Gambaran Tingkat Pengetahuan Ibu Hamil Trimester III tentang Persalinan Sectio Caesarea Di RS. Khusus Daerah Ibu dan Anak Pertiwi. Universitas Islam Negeri Alauddin Makassar.

Dinas Kesehatan. (2018a). Profil Kesehatan Indonesia. Departemen Kesehatan Republik Indonesia.

Dinas Kesehatan. (2018b). Rencana Strategis Dinas Kesehatan Kabupaten Kuningan. Departemen Kesehatan Republik Indonesia. kuningankab.go.id

Hanum, H. (2013). Faktor Risiko yang Berhubungan dengan Kejadian Preeklamsia pada Ibu Bersalin di RSUP DR. M. Djamil Padang. Jurnal Kebidanan, 2(2).

Harli, F. M. (2018). Hubungan Usia Ibu Hamil Berisiko dengan Kejadian Preeklampsia (Studi di Wilayah Kerja Puskesmas Kabuh, Puskesmas Peterongan dan Puskesmas Cukir Kabupaten Jombang). STIKes Insan Cendekia Medika Jombang.
Ciptaan disebarluaskan di bawah Lisensi Creative Commons AtribusiNonKomersial-BerbagiSerupa 4.0 Internasional.

Kementerian Kesehatan. (2016). Profil Kesehatan Provinsi Jawa Barat. Kementrian Kesehatan Jawa Barat.

Monica, D. (2017). Faktor- Faktor yang Berhubungan dengan Pemeriksaan Kehamilan Pada Ibu Hamil di Wilayah Kerja Puskesmas Kadugede Tahun 2017. Sekolah Tinggi Ilmu Kesehatan Kuningan.

Nurasiah, A., Rukmawati, A., \& Badriah, D. L. (2014). Asuhan Persalinan Normal bagi Bidan. PT Refika Aditama.

Prawihardjo, S. (2016). Ilmu Kebidanan. PT Bina Pustaka.

Rozikhan, R. (2007). Faktor-Faktor Risiko Terjadinya Preeklampsia Berat di Rumah Sakit Dr. H. Soewondo Kendal. Program Pasca Sarjana Universitas Diponegoro.

Sunarto, A. (2016). Hubungan Faktor Risiko Usia Ibu, Gravida, dan Indeks Massa Tubuh dengan Kejadian Preeklampsia di RSUD Tugurejo Semarang. UNIMUS. 